\title{
Are We Killing A Golden Goose In Goa?
}

\author{
I.K. Pai* \\ Professsor of Zoology, Goa University, India \\ *Corresponding author: I.k.Pai, Professsor of Zoology, Goa University, Goa, India
}

Submission: 眥April 03, 2018 Published: 眥April 13, 2018

\section{Opinion}

Reports of mining in Goa date back to several centuries. There are reports that Jains living in Cudnem used to extract gold in Goa. Though by early 1700's Portuguese stated iron ore mining in Goa, was not brought to the notice of the world for fear of invasion by others. However, tribe known as Dovolos, based in Navelim and other areas of Salcette extracted iron ore through the entire Portuguese period. After the World Wars as demand soared for the reconstruction mining really took off. When Goa liberated in 1961 around 800 mining permissions were granted.

The early mining in Goa was like other places were entirely manual by using pickaxes and shovels. Women and children used to carry the mines to bullock cart and then were transported to jetty to Boats or ships at Mormugao port. Later the mining became mechanized, larger, quicker, and more efficient. Explosives instead of pickaxes were used. Tracks replaced bullock carts followed by mechanized unloading and loading at Mormugao. Today, machinery within mines is becoming bigger. Trucks carry from 10 tons to 25 tons. Rail and closed conveyors are being considered as alternative transportation options. Capacity of barges has gone from 600 tons to 2,000 tons.

The rampant mining activity lead to migration into Goa for handling of machinery - trucks, barges-was the domain of men. In the process, women loststatus and their number reduced drastically. Further, this type of mining damage to mother earth multiplied. Due to mining dust fields became less and less productive; smoke from vehicles affected human health. Goa's world famous khazan bunds were damaged by the heavy speedy barges, leading to a collapse many a places. In 1987, Government of India passed the Abolition Act, which converted perpetual concessions into fixed term mining leases and erstwhile concession holders were duly compensated under the Act. At this point of time, as mining was barely profitable. It is likely that a number of questionable practices began in this time.
In the early 2000s the China boom caused iron ore prices to soar, which resulted in a mad rush to extract everything and send it to China, which lead to several malpractices in mining and also caused immense ecological only due to improper planning [1]. To counter this, several Public Interest Litigations were filed, which resulted in shut down of numerous mines on different grounds. The Shah commission's report ion mining placed in the parliament on mining was like the 'last straw on camel's back' and the subsequent ban on mining.

The commission revealed that there were numerous, serious violations by the miners. Based on the above, the Supreme Court ruled that all mining after 22-Nov-2007 was fully illegal, raising the prospect of recovering some of the loot, and making a fresh start for mining in Goa. The Supreme Court also ordered the creation of the Goa Iron Ore Permanent Fund, laying down the path for a fair to all mining system. Later the local government restarted mining by renewing leases to the same miners. When people went to court against the government's decision, in the first week of February 2018, the apex court quashed the second renewal of 88 iron ore mining leases in Goa in 2015, saying the sole motive of the companies behind the commercial activity was profit maximization and no social purpose was attached to it. The apex court in its judgment also directed to stop all mining operations in Goa with effect from March 16, 2018.

Are we killing a 'golden goose' or want to repeat the story of the phosphate-rich South Pacific island of Nauru, which was once used to be the world's richest country in terms of per capita income and later lurched toward bankruptcy?

\section{References}

1. Nayak GN (1998) Impact of mining on environment in Goa: a review. Envi geochemistry 1(2): 97-100. 
Creative Commons Attribution 4.0 International License

For possible submissions Click Here

\section{AMMS}

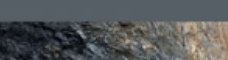

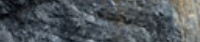

Wat $x=1$

$34=3 \times 2 \times 1=$

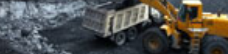

Nis

ation -10

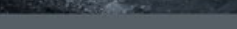

\section{Aspects in Mining \& Mineral Science}

\section{Benefits of Publishing with us}

- High-level peer review and editorial services

- Freely accessible online immediately upon publication

- Authors retain the copyright to their work

- Licensing it under a Creative Commons license

- Visibility through different online platforms 